\title{
CHEMICAL AND MOLECULAR CHARACTERIZATION OF ANATOLIAN SAGE (Salvia fruticosa Mill.) POPULATIONS DISTRIBUTED NATURALLY IN SOUTHWESTERN AEGEAN
}

\author{
Elmas, S. ${ }^{*}-$ ARABACI, O. ${ }^{2}-$ AKPINAR, E. ${ }^{3}-$ HASANCEBI, S. ${ }^{3}-$ ZEYBEK, A. $^{1}$ \\ ${ }^{I}$ Department of Biology, Faculty of Science, Mugla Sitki Kocman University, Mugla, Turkey \\ ${ }^{2}$ Department of Field Crops, Faculty of Agriculture, Adnan Menderes University, Aydin, Turkey \\ ${ }^{3}$ Department of Genetics and Bioengineering, Faculty of Engineering, Trakya University, \\ Edirne, Turkey \\ *Corresponding author \\ e-mail: sinemelmas@hotmail.com.tr; phone: +90-554-867-10-96
}

(Received $17^{\text {th }}$ Nov 2020; accepted $27^{\text {th }}$ Jan 2021)

\begin{abstract}
This study was carried out to determine the chemical, and molecular characterizations of Salvia fruticosa Mill. (Anatolian sage) populations distributed naturally in Mugla province. Plant materials were collected in June 2017 and 2018 from 30 different locations, in comprising districts of Mugla including Mentese (4), Ula (6), Koycegiz (1), Marmaris (11), Ortaca (2), Fethiye (2), Dalaman (2), and Milas (2). Thirty plants were collected from each population. The study showed the following rates: essential oil in the leaf, $0.34-3.76 \%$; essential oil in the haulm, $0.01-0.23 \%$; and total essential oil, $0.22-2.80 \%$. Genetic variation among the populations was determined by RAPD (Random Amplified Polymorphic DNA) molecular markers. In total, 150 bands were obtained from gel electrophoresis, and the populations were separated into two main clusters by evaluating these bands. Chemical and genetic profiles of Salvia fruticosa Mill. populations were determined to be compatible with each other in hierarchical clustering analysis and the created dendrograms. The different essential oil rates and components determined in the of them confirmed the genetic variation in each population.
\end{abstract}

Keywords: hydrodistillation, essential oils, RAPD-PCR, hierarchical cluster analysis, dendrogram

\section{Introduction}

The Lamiaceae family is cosmopolitan, and many species of this family have economic and medicinal importance. It is more widespread in the Mediterranean region, and in Turkey's flora, it is represented by 46 genera and 725 species (Guner et al., 2001; Elmas, 2019a). Among these, the genus Salvia is known in Turkish as "island tea," and it has been known for its pharmacological importance since ancient times (Altindal, 2019). The dried leaves of Salvia fruticosa Mill., which are economically important, are used as herbal tea or for the production of essential oil. The leaves are prepared as infusions or decoctions and consumed as tea. Water distillation from the leaves yields a colorless or light-yellow oil called Oleum Salviae trilobae, which is rich in 1,8-cineole components (Elmas, 2019a).

Salvia fruticosa Mill., which has been used for many years utilized collection from flora, has an important place in both domestic and foreign trade. In Turkey, the average sage production was 299 tonnes in the 2014-2018 period. Mugla province is important for sage cultivation and export; in Mugla, the amount of average sage production was recorded as 18.4 tonnes in 2014-2018 (TUIK, 2019).

Controlled use of economic interests and plant resources is essential for the protection of biodiversity, but many factors, such as irregular construction, intense grazing and 
unintentional harvests-where many plant species are distributed naturally-can reduce the populations of these species and jeopardize their continuity. It has been reported that Salvia fruticosa Mill. is classified as vulnerable (Elmas, 2019a). Therefore, there is an immediate need to assess the diversity of natural populations that are economically and medically valuable due to such potential threats (Bacu et al., 2005). Molecular markers, especially polymerase chain reaction (PCR)-based genetic markers, are suitable tools for identifying genetic diversity among populations. Of these, the RAPD marker is one of the simplest and most common methods used to determine the genetic similarity and diversity of populations. In addition, it has many advantages such as not needing the sequence data, ability to work with small quantity of DNA, short testing timeframe and quick results, as well as low cost (Wang et al., 2011).

The study, it was aimed to determine the structure of populations using chemical and molecular markers in Salvia fruticosa Mill. populations, which are naturally distributed in the Mugla province, Turkey, to determine the gene pools of populations and differences between them. This study can be taken as a reference to provide genetic data to the gene banks to be established in the future and reach populations with superior genotypes and phenotypes in breeding programs. This, in turn, will contribute to the development of suitable varieties for breeding and the desired product needs of enterprises.

\section{Materials and Methods}

In the study, Salvia fruticosa Mill., which is naturally distributed in the Turkey's province of Mugla was used as a plant material to investigate some of its chemical and molecular properties. The samples were collected at the end of the flowering period in June 2017 and 2018, plant materials were collected from 30 different locations in districts of Mugla including Mentese (4), Ula (6), Koycegiz (1), Marmaris (11), Ortaca (2), Fethiye (2), Dalaman (2), and Milas (2). Thirty plant materials were collected from each population. The coordinates, location, altitude of the places where Salvia fruticosa Mill. was collected are given in Table 1. These coordinates were already determined by a previous study (Elmas et al., 2019b).

\section{Chemical Studies}

In the study, essential oil rates (\%) components and their rates (\%) were determined as chemical properties.

After separating the dried plant samples into leaves and haulms, the hydro-distillation method was used to determine the essential oil rates. These rates were found volumetrically with the Neo-Clevenger apparatus (Electro-Mag) in the drog leaves and haulms (Wichtl, 1971). The gas chromatography-mass spectrometry (GC-MS) method was used for determination of essential oil components. GC-MS analyses were realized a Shimadzu (Japan) GC-2010 Plus Shimadzu GCMS-QP2010 SE (Detector) spectrometer using a Restek Rx-5Sil MS column (30 $\mathrm{m} \times 0.25 \mathrm{~mm} \times 0.25 \mathrm{um})$ (Catalog Number: Restek 1362). For GC-MS detection, an El system, with ionization energy of $70 \mathrm{eV}$, was used. Helium was the carrier gas, at a flow rate of $1.0 \mathrm{ml} / \mathrm{min}$. Injector and MS transfer line temperatures were set at $250{ }^{\circ} \mathrm{C}$ and $250{ }^{\circ} \mathrm{C}$, respectively. Diluted samples $(1 / 10$ in acetone, $\mathrm{v} / \mathrm{v})$ of $1.0 \mu \mathrm{L}$ were injected in the split (1:10 split) mode. 


$$
\text { - } 1409 \text { - }
$$

Table 1. The coordinates, locations and altitudes of where Salvia fruticosa Mill. populations were collected

\begin{tabular}{|c|c|c|c|}
\hline Population Number & Coordinates & Locations & Altitude \\
\hline \begin{tabular}{c|}
1 \\
\end{tabular} & $37^{\circ} 09^{\prime} 02.2^{\prime \prime} \mathrm{N} 28^{\circ} 25^{\prime} 16.5^{\prime \prime} \mathrm{E}$ & Yenikoy, Mentese/Mugla & 734 \\
\hline 2 & $37^{\circ} 08^{\prime} 44.7^{\prime \prime} \mathrm{N} 28^{\circ} 25^{\prime} 10.6^{\prime \prime} \mathrm{E}$ & Yenikoy, Mentese/Mugla & 772 \\
\hline 3 & $37^{\circ} 05^{\prime} 38.0^{\prime \prime} \mathrm{N} 28^{\circ} 22^{\prime} 11.1^{\prime \prime} \mathrm{E}$ & Ula, Mugla & 411 \\
\hline 4 & $37^{\circ} 04^{\prime} 50.6^{\prime \prime N} 28^{\circ} 26^{\prime} 11.6^{\prime \prime E}$ & Ula, Mugla & 613 \\
\hline 5 & $37^{\circ} 04^{\prime} 49.4^{\prime \prime} \mathrm{N} 28^{\circ} 26^{\prime} 10.6^{\prime \prime} \mathrm{E}$ & Yesilova, Ula/Mugla & 147 \\
\hline 6 & $37^{\circ} 03^{\prime} 33.0^{\prime \prime} \mathrm{N} 28^{\circ} 26^{\prime} 25.5^{\prime \prime} \mathrm{E}$ & Yesilova, Ula/Mugla & 68 \\
\hline 7 & $37^{\circ} 03^{\prime} 31.0^{\prime \prime} \mathrm{N} 28^{\circ} 26^{\prime} 21.8^{\prime \prime} \mathrm{E}$ & Elmali, Ula/Mugla & 77 \\
\hline 8 & $37^{\circ} 02^{\prime} 52.0^{\prime \prime} \mathrm{N} 28^{\circ} 17^{\prime} 17.1^{\prime \prime} \mathrm{E}$ & Kuyucak, Mentese/Mugla & 83 \\
\hline 9 & $37^{\circ} 02^{\prime} 51.0^{\prime \prime} \mathrm{N} 28^{\circ} 16^{\prime} 05.4^{\prime \prime} \mathrm{E}$ & Kiransahili, Mentese/Mugla & 162 \\
\hline 10 & $37^{\circ} 00^{\prime} 39.4^{\prime \prime} \mathrm{N} 28^{\circ} 20^{\prime} 21.0^{\prime \prime} \mathrm{E}$ & Gokce, Ula/Mugla & 75 \\
\hline 11 & $37^{\circ} 00^{\prime} 44.5^{\prime \prime} \mathrm{N} 28^{\circ} 19^{\prime} 28.1^{\prime \prime} \mathrm{E}$ & Cetibeli, Marmaris/Mugla & 112 \\
\hline 12 & $36^{\circ} 59^{\prime} 25.4^{\prime \prime} \mathrm{N} 28^{\circ} 17^{\prime} 25.4^{\prime \prime} \mathrm{E}$ & Cetibeli, Marmaris/Mugla & 295 \\
\hline 13 & $36^{\circ} 58^{\prime} 41.6^{\prime \prime} \mathrm{N} 28^{\circ} 16^{\prime} 54.5^{\prime \prime} \mathrm{E}$ & Camlikoy, Marmaris/Mugla & 65 \\
\hline 14 & $36^{\circ} 58^{\prime} 59.1^{\prime \prime} \mathrm{N} 28^{\circ} 15^{\prime} 37.1^{\prime \prime E}$ & Camlikoy, Marmaris/Mugla & 5 \\
\hline 15 & $36^{\circ} 58^{\prime} 43.6^{\prime \prime} \mathrm{N} 28^{\circ} 14^{\prime} 54.9^{\prime \prime} \mathrm{E}$ & Camlikoy, Marmaris/Mugla & 105 \\
\hline 16 & $36^{\circ} 58^{\prime} 16.2^{\prime \prime} \mathrm{N} 28^{\circ} 16^{\prime} 09.3^{\prime \prime} \mathrm{E}$ & Camlikoy, Marmaris/Mugla & 23 \\
\hline 17 & $36^{\circ} 55^{\prime} 55.6^{\prime \prime} \mathrm{N} 28^{\circ} 14^{\prime} 12.8^{\prime \prime} \mathrm{E}$ & Karaca, Marmaris/Mugla & 248 \\
\hline 18 & $36^{\circ} 56^{\prime} 34.1^{\prime \prime} \mathrm{N} 28^{\circ} 13^{\prime} 25.3^{\prime \prime} \mathrm{E}$ & Karaca, Marmaris/Mugla & 95 \\
\hline 19 & $36^{\circ} 53^{\prime} 51.6^{\prime \prime} \mathrm{N} 28^{\circ} 16^{\prime} 04.2^{\prime \prime} \mathrm{E}$ & Beldibi, Marmaris/Mugla & 287 \\
\hline 20 & $36^{\circ} 52^{\prime} 44.0^{\prime \prime} \mathrm{N} 28^{\circ} 14^{\prime} 41.8^{\prime \prime} \mathrm{E}$ & Marmaris, Mugla & 259 \\
\hline 21 & $36^{\circ} 52^{\prime} 22.301^{\prime \prime N} 28^{\circ} 14^{\prime} 38.323^{\prime \prime E}$ & Armutalan, Marmaris/Mugla & 183 \\
\hline 22 & $36^{\circ} 53^{\prime} 37.7^{\prime \prime} \mathrm{N} 28^{\circ} 35^{\prime} 19.5^{\prime \prime} \mathrm{E}$ & Sultaniye, Koycegiz/Mugla & 26 \\
\hline 23 & $36^{\circ} 43^{\prime} 59.4^{\prime \prime} \mathrm{N} 28^{\circ} 40^{\prime} 51.4^{\prime \prime} \mathrm{E}$ & Sarigerme, Ortaca/Mugla & 99 \\
\hline 24 & $36^{\circ} 43^{\prime} 35.2^{\prime \prime} \mathrm{N} 28^{\circ} 51^{\prime} 39.8^{\prime \prime} \mathrm{E}$ & Serefler, Dalaman/Mugla & 238 \\
\hline 25 & $36^{\circ} 47^{\prime} 36.9^{\prime \prime N} 28^{\circ} 39^{\prime} 42.7^{\prime \prime E}$ & Dalyan, Ortaca/Mugla & 3 \\
\hline 26 & $37^{\circ} 6^{\prime} 17.584$ "N 27054'36.224"E & Cakiralan, Milas/Mugla & 290 \\
\hline 27 & $37^{\circ} 2^{\prime} 37.912$ "N 27º54'21.589"E & Turkevleri, Milas/Mugla & 43 \\
\hline 28 & 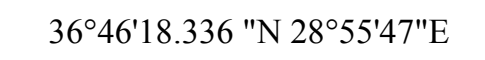 & Gocek, Fethiye/Mugla & 182 \\
\hline 29 & $36^{\circ} 48^{\prime} 35.831^{\prime \prime} \mathrm{N} 28^{\circ} 56^{\prime} 11.49^{\prime \prime} \mathrm{E}$ & Akarca, Dalaman/Mugla & 256 \\
\hline 30 & $36^{\circ} 45^{\prime} 39.452^{\prime \prime} \mathrm{N} 28^{\circ} 58^{\prime} 23.139^{\prime \prime} \mathrm{E}$ & Gocek, Fethiye/Mugla & 199 \\
\hline
\end{tabular}

\section{Molecular Studies}

\section{DNA isolation}

While starting the isolation, the tissues were dissected with the help of a homogenizer (Retsch MM400) using liquid nitrogen. Instead of Falcon tubes, $2 \mathrm{ml}$ sample tubes were used and the prepared solution was added to the disrupted tissues and mixed in a homogenizer for 1 minute. In addition, the amount of $\mathrm{NaCl}$ in the homogenization buffer was used as $4 \mathrm{M}$ instead of $6 \mathrm{M}$. In collecting DNA, centrifuge was used instead of glass pipette and the washing step was repeated 2 times. Genomic DNAs (gDNA) were extracted from the drog leaves of Salvia fruticosa Mill. for the DNA isolation, the extraction method described in Aljanabi et al.'s (1999) was modified and applied. 


\section{Determination of DNA quantity and quality}

Concentration of gDNAs were detected as $\mathrm{ng} / \mu \mathrm{l}$ by spectrophotometer (OPTIZEN NanoQ). The quality of gDNAs were observed on agarose gel $(0.8 \%)$. Agarose gel electrophoresis (Invitrogen Ultrapure Agarose, Catalog number: 16500500) was carried out for 1 hour at $100 \mathrm{~V}, 80 \mathrm{~mA}$. Following this, the DNA quality of the samples was monitored under ultraviolet (UV) light on a gel imaging device.

\section{Molecular marker analyses}

gDNAs from the leaves of Salvia fruticosa Mill. was used for molecular analysis. In RAPD analysis, 15 RAPD primers (Table 2) which is high polymorphic for Salvia were selected from reported studies. As a result of the literature search for molecular marker analysis, RAPD markers-which are the most polymorphic for Salvia species-were employed (Skoula et al., 1999; Javan et al., 2012).

Table 2. All primers used in the Salvia fruticosa Mill. molecular analysis, the number of bands formed by the band generating primers, and band sizes

\begin{tabular}{|c|c|c|c|c|}
\hline Primers & Name of primers & 5'-Base Sequence-3' & Numbers of bands & Bands size \\
\hline 1 & OPA-03 & AGT CAG CCA C & 19 & $250-3000 \mathrm{bp}$ \\
\hline 2 & OPA-04 & AAT CGG GCT G & 19 & $450-3000 \mathrm{bp}$ \\
\hline 3 & OPA-05 & AGG GGT CTT G & 8 & $300-3000 \mathrm{bp}$ \\
\hline 4 & OPA-06 & GGT CCC TGA C & 0 & - \\
\hline 5 & OPA-07 & GAA ACG GGT G & 18 & $200-3000 \mathrm{bp}$ \\
\hline 6 & OPB-01 & GTT TCG CTC C & 0 & - \\
\hline 7 & OPB-02 & TGA TCC CTG G & 0 & - \\
\hline 8 & OPB-03 & CAT CCC CCA G & 0 & - \\
\hline 9 & OPB-04 & GGA CTG GAG T & 0 & - \\
\hline 10 & OPB-05 & TGC GCC CTT C & 15 & $600-3000 \mathrm{bp}$ \\
\hline 11 & OPD-02 & GGA CCC AAC C & 14 & $550-2500 \mathrm{bp}$ \\
\hline 12 & OPD-03 & GTC GCC GTC A & 12 & $300-3000 \mathrm{bp}$ \\
\hline 13 & OPD-05 & TGA GCG GAC A & 10 & $300-3000 \mathrm{bp}$ \\
\hline 14 & OPD-08 & GTG TGC CCC A & 16 & $250-3000 \mathrm{bp}$ \\
\hline 15 & OPD-11 & AGC GCC ATT G & 19 & $450-3000 \mathrm{bp}$ \\
\hline Total & & & 150 & \\
\hline
\end{tabular}

PCR reactions performed in total $25 \mu 1$ PCR reaction 1x PCR buffer, $30 \mathrm{ng}$ of genomic DNA, 1 unit Taq DNA polymerase, $2 \mathrm{mM} \mathrm{MgCl}$, O. $2 \mathrm{mM}$ each dATP, dCTP, dGTP, dTTP and $0.15 \mathrm{mM}$ RAPD primer. Amplification was performed in Mycycler thermocycler (Biorad T100) as follows; $3 \mathrm{~min}$ at $94^{\circ} \mathrm{C}, 1 \mathrm{~min}$ at $94^{\circ} \mathrm{C}, 1 \mathrm{~min}$ at 50, 55, $60^{\circ} \mathrm{C}$ (depending on the annealing temperature), $1 \mathrm{~min}$ at $72^{\circ} \mathrm{C}$ for 40 cycles with $10 \mathrm{~min}$ final extension at $72^{\circ} \mathrm{C}$. PCR reactions were analysed by $1.5 \%$ agarose gel.

\section{Evaluation of Data}

Ten out of the 15 primers shown in Table 2 yielded reproducible and reliable amplified DNA products. These amplified DNA fragments were evaluated for genetic diversity of Salvia fruticosa Mill. The amplified RAPD bands were scored as 1 or 0 depending on the presence or absence on gel to create the excel tables. Populations and primers were entered using the GenAlex 6.5 software (Peakall and Smouse, 2012). With the unweighted pair group method with arithmetic mean (UPGMA) method, a genetic proximity-distance dendrogram as standardized by Nei (1978) was created. Hierarchical 


$$
-1411 \text { - }
$$

clustering analysis and dendrogram were generated by SPSS Statistics v 22 program; these showed the proximity and distance between the populations in terms of chemical components examined.

\section{Results and Discussion}

\section{Chemical Results}

As shown in Table 3, the average essential oil rate of leaves in the populations varied in the range of $0.34-3.76 \%$, the average essential oil rate of the haulm was $0.01-0.23 \%$, and the average total essential oil rate was $0.22-2.80 \%$. The essential oil rates of the Salvia fruticosa Mill. species determined in the study are compatible with those determined by Karousou and Kokkini (1997), Mossi et al. (2011), and Karik (2015).

Table 3. Average values of essential oil rates of Salvia fruticosa Mill. in 2017 and 2018

\begin{tabular}{|c|c|c|c|}
\hline $\begin{array}{c}\text { Populati } \\
\text { ons }\end{array}$ & $\begin{array}{c}\text { The Rates of Essential Oil in } \\
\text { The Leaf }(\%)\end{array}$ & $\begin{array}{c}\text { The Rates of Essential Oil in } \\
\text { The Haulm (\%) }\end{array}$ & $\begin{array}{l}\text { The Total Rates of } \\
\text { Essential Oil (\%) }\end{array}$ \\
\hline 1.P & 0.56 & 0.03 & 0.28 \\
\hline 2.P & 0.34 & 0.03 & 0.22 \\
\hline 3.P & 2.75 & 0.19 & 1.98 \\
\hline 4.P & 2.67 & 0.18 & 1.24 \\
\hline 5.P & 2.92 & 0.16 & 1.95 \\
\hline 6.P & 3.76 & 0.20 & 1.99 \\
\hline 7.P & 2.29 & 0.10 & 1.24 \\
\hline 8.P & 2.99 & 0.05 & 1.42 \\
\hline 9.P & 2.55 & 0.01 & 1.45 \\
\hline 10.P & 2.48 & 0.04 & 1.30 \\
\hline 11.P & 2.20 & 0.05 & 1.27 \\
\hline 12.P & 1.93 & 0.02 & 1.06 \\
\hline 13.P & 2.97 & 0.03 & 1.62 \\
\hline 14.P & 2.26 & 0.08 & 1.30 \\
\hline 15.P & 3.09 & 0.09 & 1.91 \\
\hline 16.P & 1.97 & 0.07 & 1.46 \\
\hline 17.P & 2.49 & 0.09 & 1.36 \\
\hline 18.P & 2.96 & 0.13 & 1.70 \\
\hline 19.P & 3.39 & 0.20 & 2.80 \\
\hline 20.P & 2.21 & 0.13 & 1.37 \\
\hline 21.P & 2.18 & 0.09 & 1.31 \\
\hline 22.P & 3.38 & 0.13 & 1.88 \\
\hline 23.P & 2.93 & 0.15 & 1.48 \\
\hline 24.P & 2.62 & 0.06 & 1.64 \\
\hline 25.P & 3.14 & 0.17 & 1.81 \\
\hline 26.P & 2.93 & 0.08 & 1.43 \\
\hline 27.P & 2.89 & 0.23 & 1.79 \\
\hline 28.P & 2.81 & 0.22 & 1.70 \\
\hline 29.P & 2.72 & 0.13 & 1.39 \\
\hline 30.P & 2.77 & 0.19 & 1.24 \\
\hline Average & 2.57 & 0.11 & 1.49 \\
\hline $\begin{array}{l}\text { S.D. } \\
\end{array}$ & 0.7 & 0.06 & 0.48 \\
\hline
\end{tabular}

The components of essential oils in Salvia fruticosa Mill. populations collected from flora in 2017 and 2018 were determined using the GC-MS method, and their average components and distribution according to the populations are given in Table 4. The rates 
of 1,8-cineole, camphor, camphene, $\alpha$-pinene-some of the major essential oil components of Salvia fruticosa Mill. - determined by GC-MS analysis showed wide variation among the populations, and the results are compatible with those of Bayram (2001), Uysal (2015), and Karik (2015), who previously studied this species.

Table 4. Average of principal chemical components of Salvia fruticosa Mill. populations collected in 2017 and 2018 and distribution by population (\%)

\begin{tabular}{|c|c|c|c|c|c|c|c|c|c|c|c|c|}
\hline $\begin{array}{c}\text { Populat } \\
\text { ions }\end{array}$ & $\begin{array}{c}\alpha- \\
\text { Humule } \\
\text { ne }\end{array}$ & $\begin{array}{c}\alpha- \\
\text { Pinen } \\
\text { e }\end{array} \mid$ & $\begin{array}{c}\alpha- \\
\text { Thujo } \\
\text { ne }\end{array}$ & \begin{tabular}{|c|}
$1,8-$ \\
Cineol \\
$\mathrm{e}$
\end{tabular} & $\begin{array}{c}\beta- \\
\text { Pinen } \\
\text { e }\end{array}$ & $\begin{array}{l}\text { Camp } \\
\text { hene }\end{array}$ & $\begin{array}{l}\text { Camp } \\
\text { hor }\end{array}$ & $\begin{array}{c}\text { Trans } \beta- \\
\text { Caryophyllene }\end{array}$ & $\begin{array}{c}\text { Caryoph } \\
\text { yllene } \\
\text { oxide }\end{array}$ & $\begin{array}{c}\text { Cy } \\
\text { mol }\end{array}$ & $\begin{array}{c}\beta- \\
\text { Myrc } \\
\text { ene }\end{array}$ & $\begin{array}{c}\text { Thuje } \\
\text { ne-a }\end{array}$ \\
\hline 1.P & 3.98 & 30.46 & 0.0 & 38.72 & 3.56 & 1.17 & 1.09 & 0.88 & 1.96 & 0.0 & 1.51 & 0.37 \\
\hline 2.P & 3.72 & 19.93 & 0.08 & 24.62 & 17.82 & 0.88 & 2.24 & 0.78 & 1.29 & 1.07 & 1.78 & 0.38 \\
\hline 3.P & 1.43 & 5.26 & 0.50 & 59.90 & 3.62 & 0.54 & 1.15 & 2.57 & 15.00 & 0.24 & 6.79 & 0.26 \\
\hline 4.P & 1.26 & 4.88 & 1.76 & 59.38 & 3.55 & 1.21 & 2.63 & 3.56 & 0.55 & 0.58 & 2.43 & 0.15 \\
\hline 5.P & 0.62 & 4.78 & 2.88 & 50.65 & 6.86 & 1.82 & 6.26 & 2.68 & 0.45 & 0.58 & 2.67 & 0.45 \\
\hline 6.P & 0.67 & 4.32 & 3.47 & 58.40 & 6.91 & 1.02 & 3.73 & 3.63 & 0.40 & 0.44 & 3.07 & 0.32 \\
\hline 7.P & 1.17 & 5.46 & 1.54 & 53.58 & 6.02 & & 5.17 & 2.49 & 0.56 & 0.64 & 3.77 & 0.22 \\
\hline 8.P & 2.00 & 3.81 & 1.69 & 45.16 & 4.75 & 2.03 & 8.52 & 2.90 & 0.64 & 0.55 & 2.46 & 0.12 \\
\hline 9.P & 0.87 & 4.99 & 3.55 & 55.75 & 5.99 & 1.25 & 2.77 & 2.66 & 0.38 & 0.59 & 3.41 & 0.20 \\
\hline 10.P & 1.26 & 6.85 & 1.22 & 53.21 & 7.83 & 2.77 & 3.85 & & 0.43 & 0.29 & 1.90 & 0.30 \\
\hline 11.P & 1.04 & 6.01 & 1.12 & 53.75 & 7.19 & 2.85 & 5.27 & 4.0 & 0.48 & 0.57 & 2.57 & 0.16 \\
\hline 12.P & 1.00 & 5.39 & 1.03 & 58.14 & 2.99 & & 1.03 & 4.20 & 0.52 & 0.69 & 4.02 & 0.23 \\
\hline 13.P & 0.60 & 5.33 & 0.92 & 56.13 & 7.56 & 2.57 & 4.52 & 2.33 & 0.46 & 0.41 & 4.60 & 0.28 \\
\hline 14.P & 1.32 & 5.54 & 0.47 & 59.83 & 8.80 & 51 & 1.54 & 2.36 & 0.55 & 0.45 & 3.11 & 0.30 \\
\hline 15.P & 0.68 & 5.95 & 1.04 & 50.61 & 4.68 & 4.50 & 9.03 & 2.92 & 0.37 & 0.41 & 2.68 & 0.12 \\
\hline 16.P & 1.01 & 5.37 & 0.59 & 49.39 & 3.51 & & 9.68 & & 0.38 & 0.59 & 5.10 & 0.15 \\
\hline 17.P & 1.42 & 5.59 & 0.66 & 54.58 & 7.46 & & 3.76 & 4.03 & 0.50 & 0.11 & 3.66 & 0.11 \\
\hline 18.P & 1.28 & 5.22 & 0.79 & 58.99 & 7.60 & 1.58 & 2.75 & 1.68 & 0.34 & 0.40 & 2.90 & 0.29 \\
\hline 19.P & 0.72 & 4.32 & 1.14 & 61.01 & 3.61 & & 2.24 & 3.6 & 0.45 & 0.28 & 2.54 & 0.10 \\
\hline 20.P & 1.05 & 5.11 & 0.83 & 60.15 & 6.18 & 1.26 & 2.91 & 4.54 & 0.51 & 0.27 & 3.26 & 0.22 \\
\hline 21.P & 1.41 & 5.24 & 0.63 & 59.27 & 3.38 & & 1.63 & 4.31 & 0.48 & 0.49 & 6.72 & 0.30 \\
\hline 22.P & 0.54 & 4.82 & 3.91 & 56.31 & 6.38 & 1.51 & 2.71 & 2.35 & 0.56 & 0.54 & 3.79 & 0.45 \\
\hline 23.P & 0.81 & 4.41 & 4.02 & 57.38 & 5.98 & 1.18 & 2.17 & 2.93 & 0.39 & 0.56 & 4.69 & 0.32 \\
\hline 24.P & 0.6 & 4.68 & 2.55 & 54.97 & 5.29 & 2.24 & 7.4 & 1.80 & 0.50 & 0.31 & 3.7 & 0.12 \\
\hline 25.P & 0.7 & 4.37 & 3.61 & 57.82 & 6.58 & 0.88 & 2.4 & 4.01 & 0.36 & 0.44 & 6.2 & 0.33 \\
\hline 26.P & 1.0 & 5.44 & 0.64 & 62.47 & 6.77 & 1.08 & 2.3 & 2.59 & 0.42 & 0.57 & 7.4 & 0.15 \\
\hline 27.P & 1.0 & 5.03 & 2.52 & 57.31 & 6.23 & 1.74 & 4.8 & 3.61 & 0.52 & 0.59 & 5.6 & 0.16 \\
\hline 28.P & 1.2 & 4.47 & 2.44 & 60.52 & 6.78 & 1.39 & 2.9 & 2.10 & 0.28 & 0.52 & 5.7 & 0.33 \\
\hline 29.P & 1.5 & 4.03 & 1.82 & 59.76 & 6.06 & 1.30 & 8.1 & 3.41 & 0.41 & 0.57 & 5.0 & 0.15 \\
\hline 30.P & 0.9 & 5.06 & 2.92 & 58.89 & 6.47 & 1.67 & 4.0 & 1.68 & 0.23 & 0.73 & 4.9 & 0.32 \\
\hline Av. & 1.23 & 6.40 & 1.68 & 54.89 & 6.21 & 1.67 & 3.95 & 3.05 & 1.01 & 0.48 & 3.93 & 0.25 \\
\hline S.D. & 0.79 & 5.33 & 1.21 & 7.64 & 2.70 & 0.94 & 2.47 & 1.34 & 2.66 & 0.20 & 1.59 & 0.10 \\
\hline
\end{tabular}

Table 5 shows the relationships between populations in terms of essential oil components. For the clustering analysis, it was determined that the populations were separated into two main clusters and subclusters within them. 
Table 5. Hierarchical clustering analysis showing the relationships between genotypes in terms of chemical properties of Salvia fruticosa Mill. (Squared Euclidean Distance)

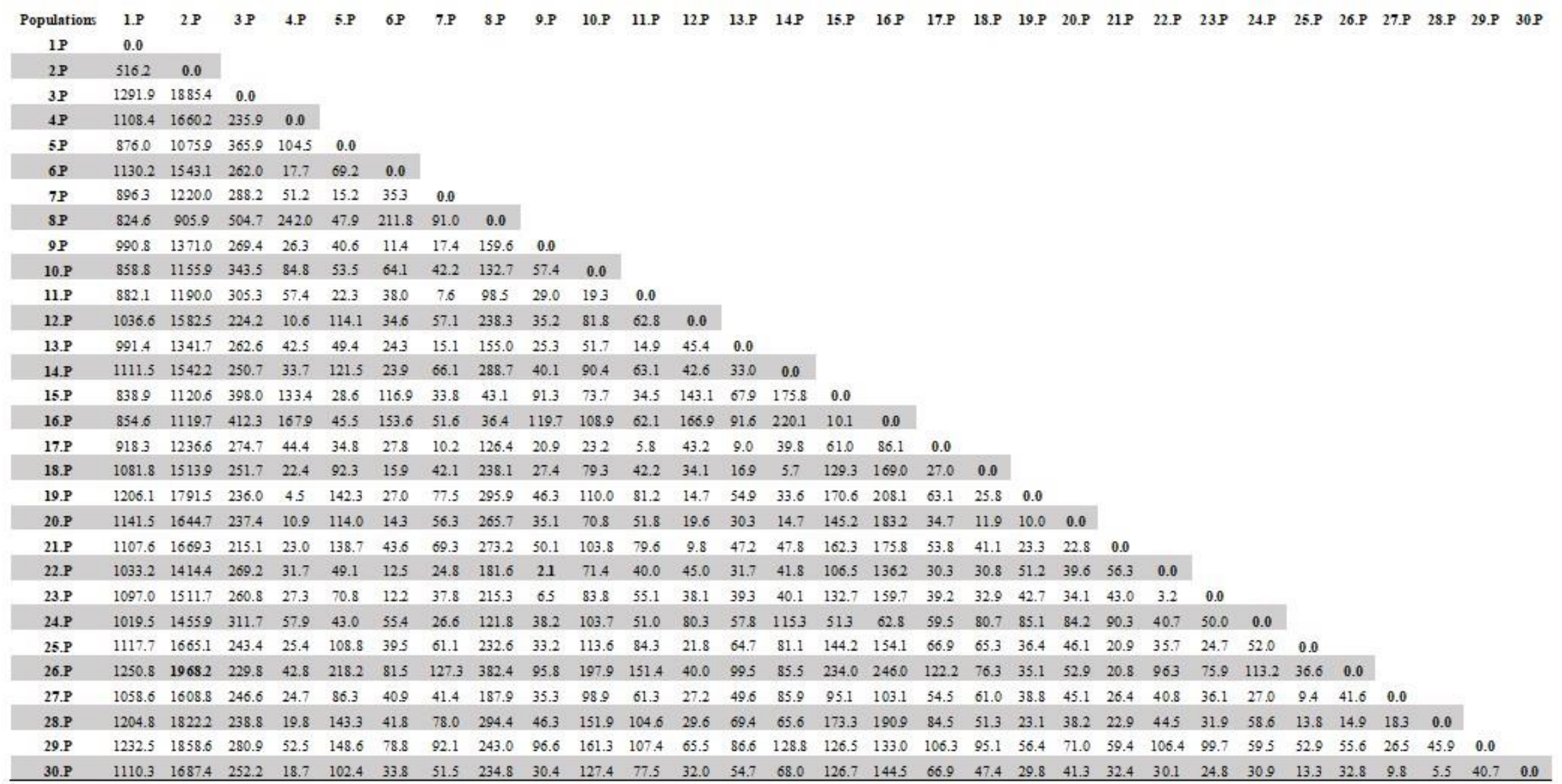




$$
-1414 \text { - }
$$

As illustrated in Figure 1, yellow-marked populations 1 and 2 formed the first cluster, while red-marked populations $5,7,8,10,11,13,15,16$, and 17 and blue-marked populations $3,4,6,9,12,14,18,19,20,21,22,23,24,25,26,27,28,29$, and 30 formed the second cluster. In the dendrogram in Figure 2, it is shown that populations 1 and 2 from Yenikoy are distinctly separated from other populations and form a spontaneous cluster. The populations closest to each other in terms of the proportions of the components are populations 9 and 22 (Euclidean distance: 2.1 ). Following this, the closest populations were determined as 22 (Koycegiz) and 23 (Ortaca) and 4 (Ula) and 19 (Marmaris; Euclidean distances: 3.2 and 4.5, respectively). As a result of the hierarchical clustering analysis, the most distant populations were identified as populations 2 (Yenikoy) and 26 (Milas; Euclidean distance: 1,968.2). The next farthest populations were 2 (Yenikoy) and 3 (Ula) and 2 and 29 (Dalaman; Euclidean distances: 1,885.4 and 1,858.6, respectively). While populations from Fethiye (28 and 30), Milas (26 and 27), Ortaca (23 and 25), and Dalaman (24 and 29) were clustered tightly, it was determined that populations from Marmaris, Ula, and Mentese were distributed in separate subsets.

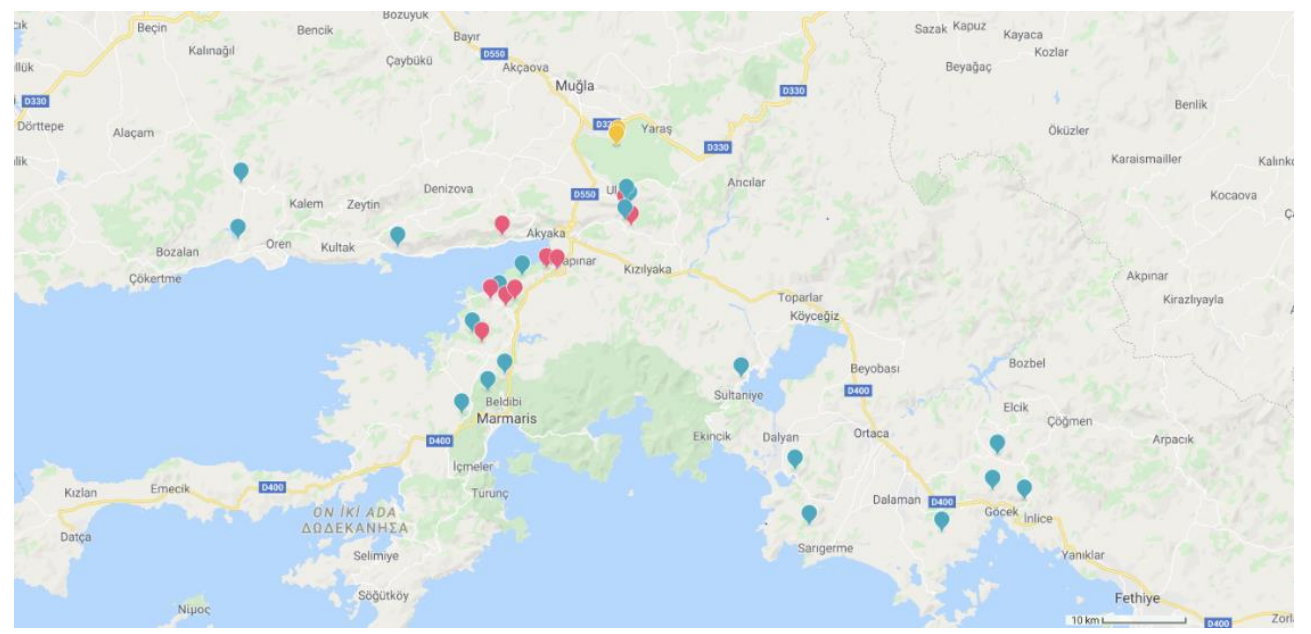

Figure 1. Map image of clusters of Salvia fruticosa Mill. populations according to chemical markers

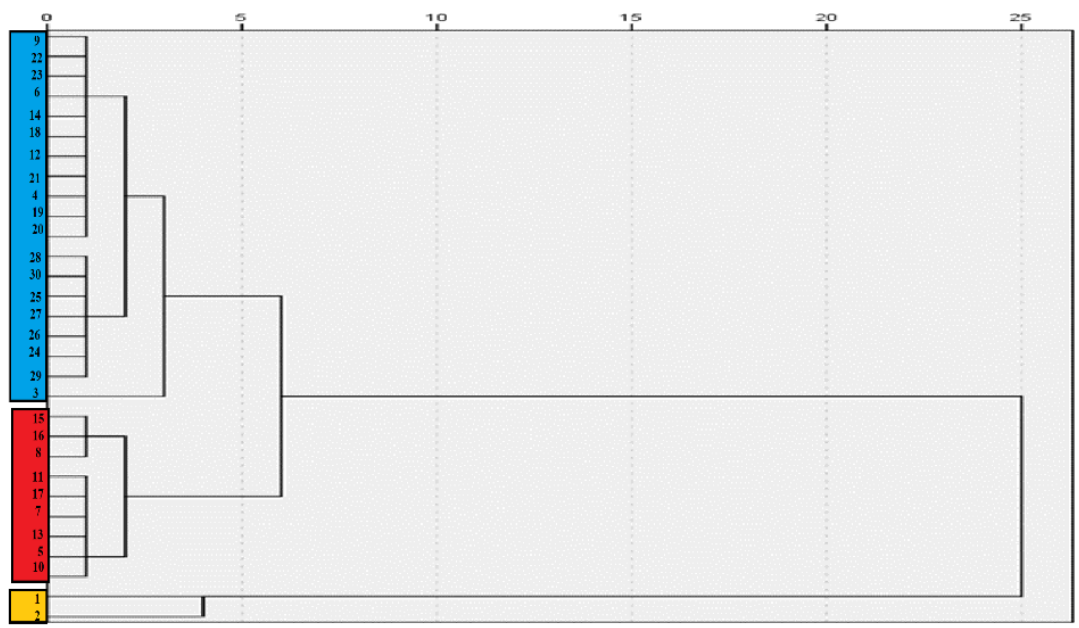

Figure 2. Dendogram of the relationships between populations in terms of rates of chemical components of Salvia fruticosa Mill. 


$$
-1415 \text { - }
$$

\section{Molecular Marker Analysis}

The amplified products from RAPD loci from each sample were separated by gel electrophoresis. In total 150 DNA bands were produced and evaluated. The bands were scored as 1 or 0 according to the presence and absence of bands. The agarose gel images of RAPD-PCR analysis with isolated DNA from the leaves of Salvia fruticosa Mill. are given in Figure 3.

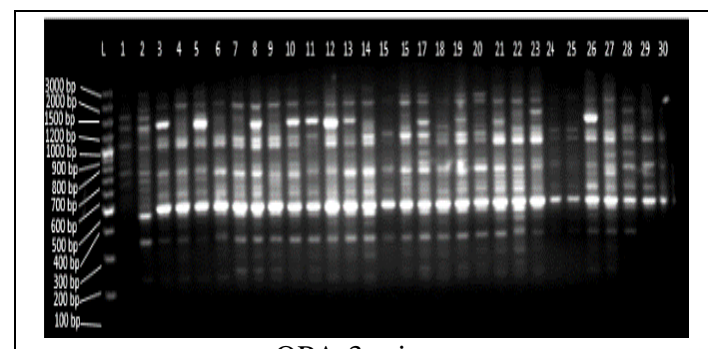

OPA-3 primer

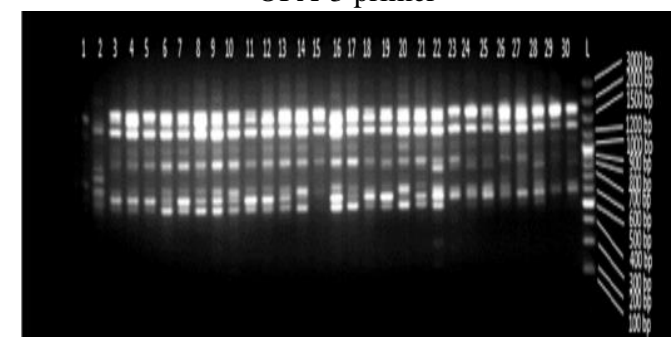

OPA-5 primer

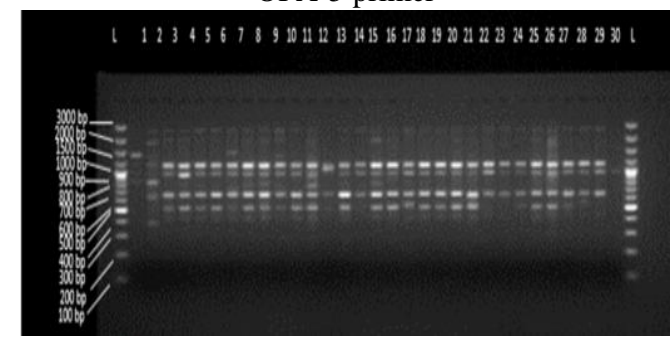

OPB-5 primer

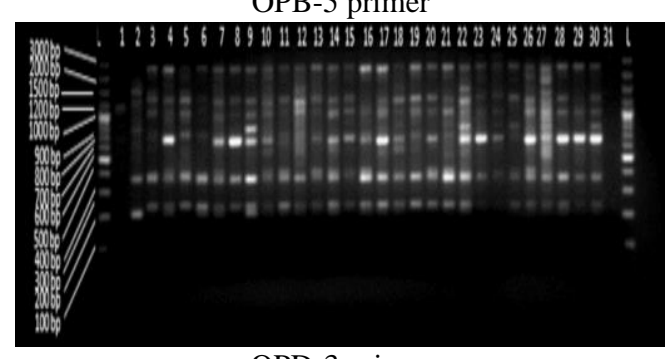

OPD-3 primer

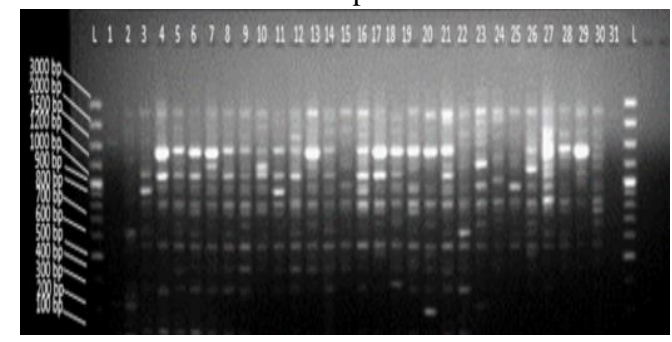

OPD-8 primer

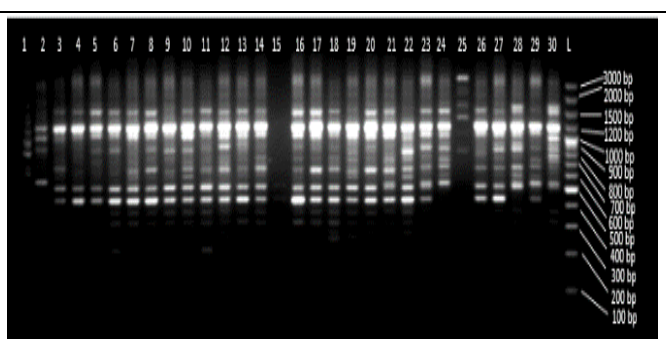

OPA-4 primer

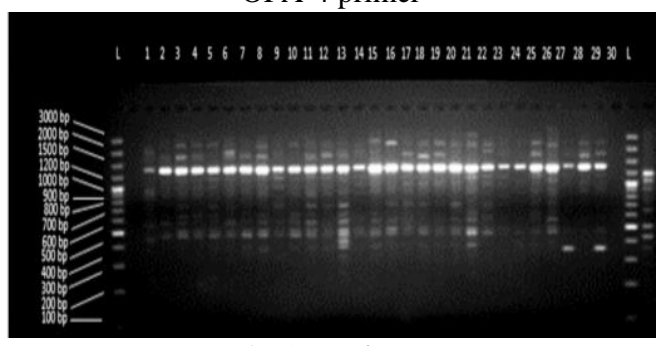

OPA-7 primer

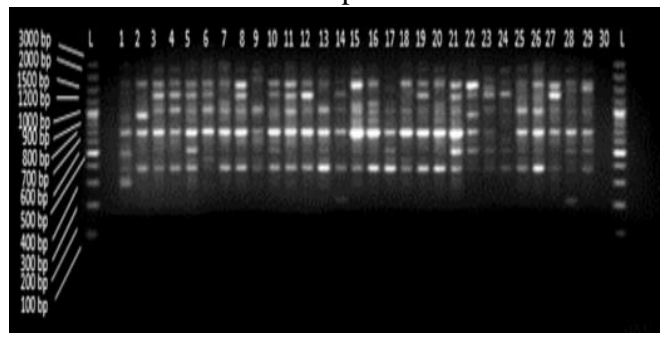

OPD-2 primer

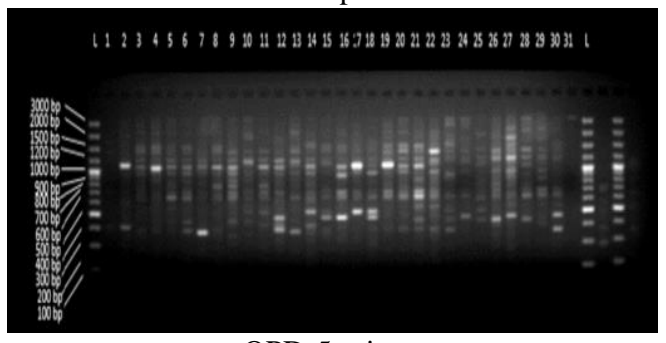

OPD-5 primer

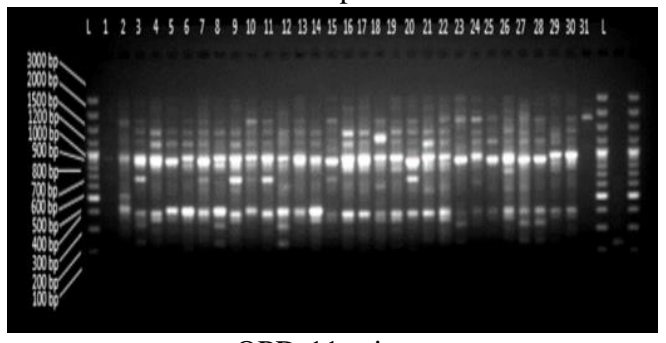

OPD-11 primer

Figure 3. Agarose gel images of RAPD-PCR products obtained from drog leaf with primers 
The values showing genetic relationships among Salvia fruticosa Mill. populations collected from nature in the Mugla region are given in Table 6. In addition, dendrograms showing genetic relationships between populations are given in Figure 4. As a result of the analyses illustrated in Figure 4, it is shown that populations are genetically divided into two main clusters.

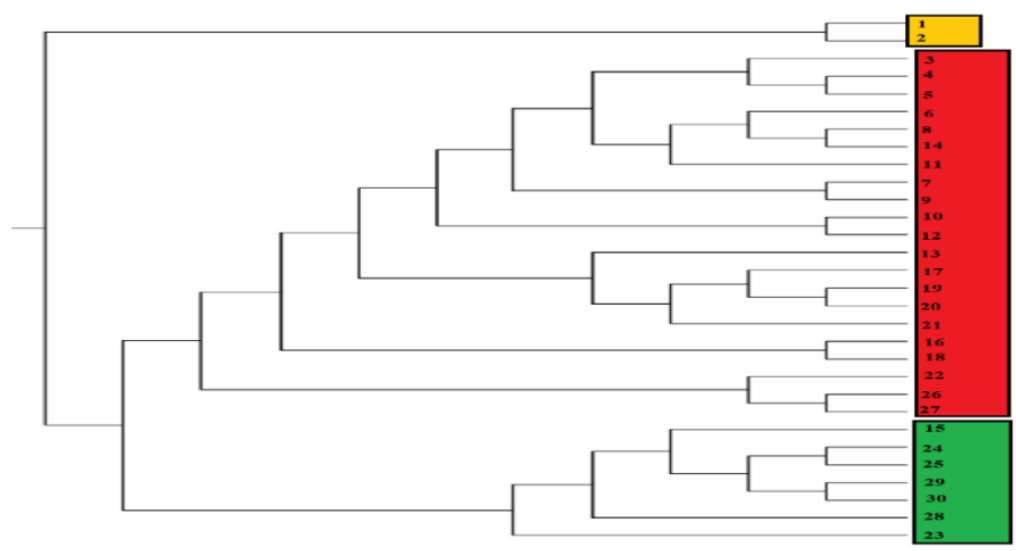

Figure 4. Dendrogram showing the genetic relationship between Salvia fruticosa Mill. populations

As shown in Figure 5, yellow-marked populations 1 and 2 formed the first cluster, while green-marked populations 15, 23, 24, 25, 28, 29, and 30 and red-marked populations $3,4,5,6,7,8,9,10,11,12,13,14,16,17,18,19,20,21,22,26$, and 27 formed the second cluster. In the UPGMA dendrogram in Figure 4, it can be observed that populations 1 and 2 from Yenikoy are distinctly separate from the other populations. The genetic distances of the populations are as follows: Fethiye and Marmaris, 32.348.8\%; Fethiye and Ula, 33.2-45.5\%; Fethiye and Ortaca, 30.4-44.4\%; Fethiye and Dalaman, 22.3-38.2\%; Fethiye and Mentese, 40.2-64.6\%; Fethiye and Milas, 34.2$39.2 \%$; and Fethiye and Koycegiz, 40.2-41.2\%. The genetic distance between populations 28 and 30 collected from Fethiye is $27.6 \%$. The distance between the Marmaris and Mentese populations is $16.5-83.4 \%$, that of Marmaris and Ortaca is 30.4$59.5 \%$, that of Marmaris and Koycegiz is $28.5-59.5 \%$, that of Marmaris and Dalaman is 32.3-55.8\%, that of Marmaris and Ula is 17.3-48.8\%, and that of Marmaris and Milas is 26.7-47.7\%. The genetic distance of the Marmaris populations is 15.7-59.5\%. As shown in Table 6, the most genetically distant populations were determined as 1 (Yenikoy) and 22 (Sultaniye, Koycegiz; genetic distance value: 0.88), followed by populations 2 (Yenikoy) and 20 (Marmaris) and 1 (Yenikoy) and 21 (Marmaris; genetic distance value of both: 0.83 ).

The genetically closest populations were populations 4 and 5, both collected from Ula (genetic distance value: 0.14). The next closest populations were populations 19 and 20 (Marmaris; genetic distance value: 0.15). Skoula et al. (1999) used the RAPD-PCR method to search the effect of genotype on the chemical profile of the Salvia fruticosa Mill. species and determined that there is genetic diversity both within and between populations; the same finding was evident in our study. In their research, the different essential oil rates and component's rates determined in the populations confirmed the genetic variability in each population. Skoula et al.'s (1999) results are compatible with the results obtained in our study. 
Table 6. Genetic distance matrix between Salvia fruticosa Mill. genotypes

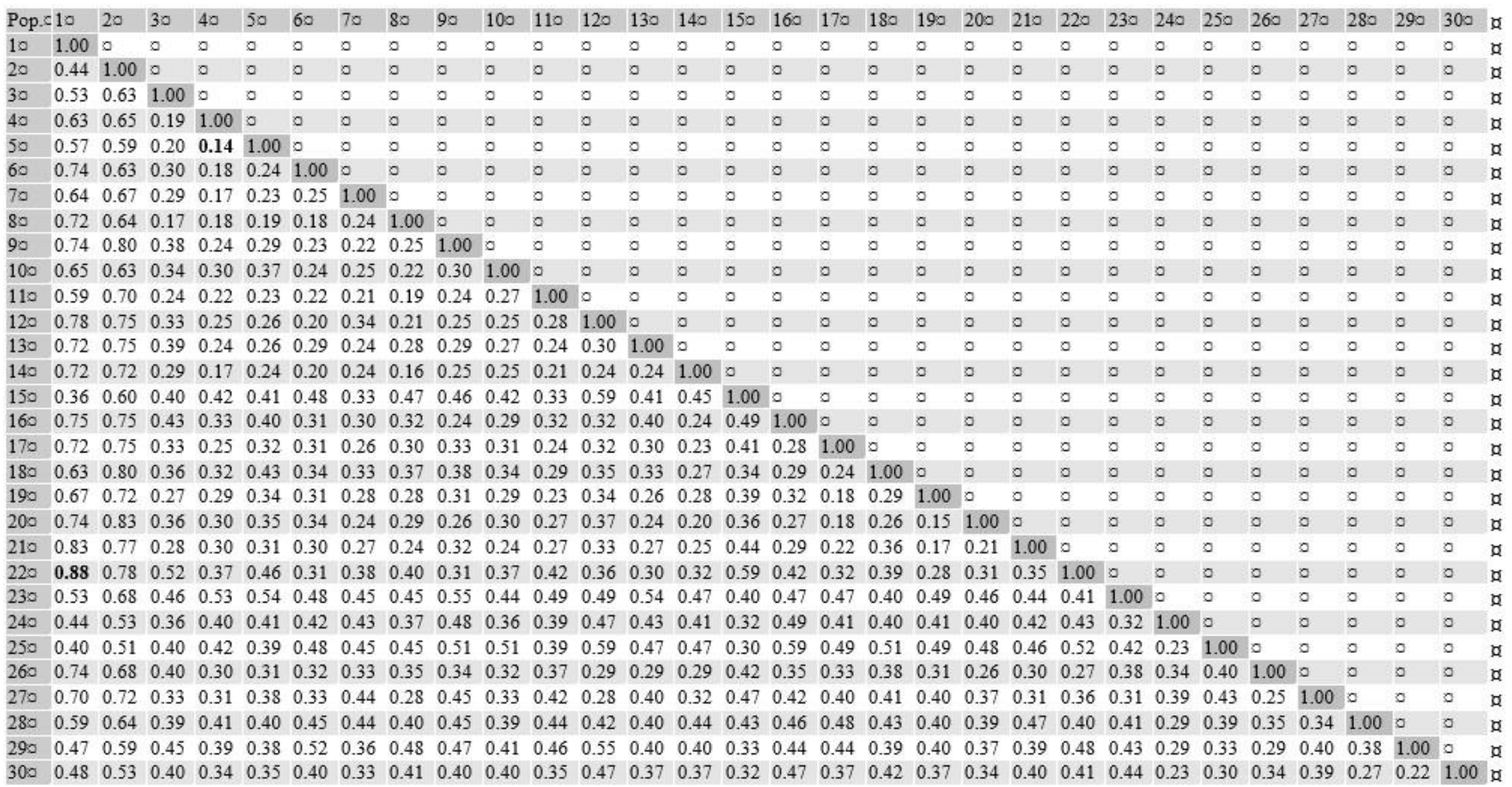

APPLIED ECOLOGY AND ENVIRONMENTAL RESEARCH 19(2):1407-1421.

http://www.aloki.hu • ISSN 15891623 (Print) • ISSN1785 0037 (Online)

DOI: http://dx.doi.org/10.15666/aeer/1902_14071421

(c) 2021, ALÖKI Kft., Budapest, Hungary 


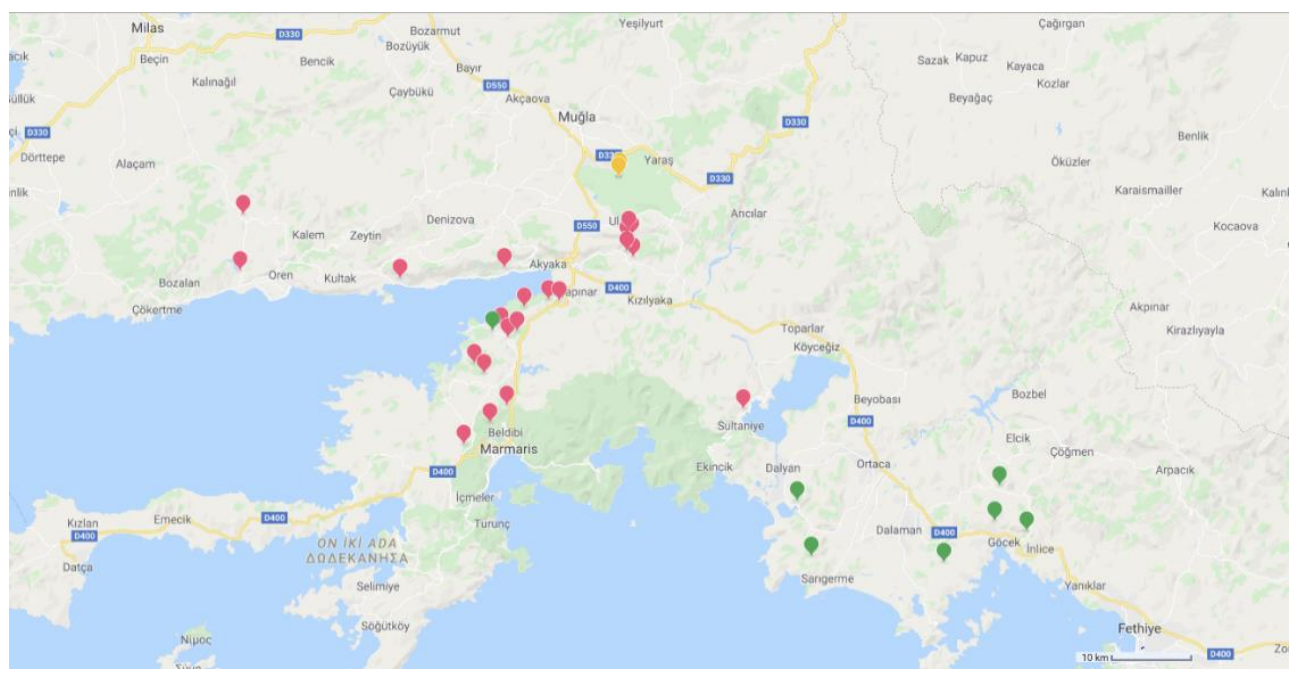

Figure 5. Map image of clusters of Salvia fruticosa Mill. populations according to molecular markers

In another study carried out in Mugla province, Altindal (2019) determined the genetic relationships in natural sage populations collected from the Fethiye, Gocek, Dalaman, Koycegiz, Yerkesik, Dalyan, Marmaris, and Bodrum districts. In the dendrogram, Dalyan, Koycegiz, Marmaris, and Bodrum were in the first group, while Gocek, Dalaman, and Fethiye formed the second group; the sages belonging to the Yerkesik region formed a spontaneous group. The highest genetic similarity rate was determined in the Koycegiz and Bodrum populations and the lowest between the Yerkesik and Bodrum populations. The molecular method used by Altindal (2019) to determine genetic relationships is different from that in our study, but the dendrogram in which the genetic relationships are shown is similar to ours.

\section{Conclusion}

In this study on Salvia fruticosa Mill., which has a natural distribution in Mugla province, it was determined that there is wide chemical and genetic variation both within and among the populations. In the study, while within-population differences essential oil rates and components were determined by comparing them with the mean values of that population, differences between populations were determined by comparing the essential oil ratios in other populations and their mean value of components and by molecular analyses. In hierarchical clustering analysis and dendrogram, chemical and genetic profiles of Salvia fruticosa Mill. populations were found to be compatible with each other.

The differences between dendrograms may be due to a number of complex linkages, such as gene expression between phenotypes and genotypes, as well as the morphological and chemical characteristics of plants, which may change with the environment and gene exchange between species during natural selection. In the study, the genetic proximity of populations that are geographically close to each other showed that there was gene flow between populations (Skoula et al., 1999). The different rates and components of essential oils determined in the populations also confirmed that there is genetic variability in each population. 
The chemical properties of medicinal and aromatic plants may vary depending on their genetic profile, and the geographical and climatic conditions in which they distributed naturally. In this study, Salvia fruticosa Mill. both essential oil rates and components showed wide variation in populations. Different biotic (bacteria, fungus, virus, etc.) and abiotic stress factors (drought, salinity, radiation, light, low or high temperatures, nutrient deficiencies, etc.), which were reported to cause changes in the chemical structure of the Salvia fruticosa Mill. plant in previous studies, may be the reason for the wide variation in chemical properties among the populations in this study (Arikat et al., 2004; Chrysargyris et al., 2016) In previous studies carried out on Salvia fruticosa Mill. it has been reported that the plant produces anatomical, physiological and morphological changes in its structure as well as changes in its chemical structure in order to overwhelm these factors that cause stress. The reason for the wide variation in the rates and components of Salvia fruticosa Mill. essential oil among the populations may be due to genetic characteristics, environmental, climatic conditions and the effect of each of different stress factors or a combination of all these factors.

Salvia fruticosa Mill. populations, which have a natural distribution in Mugla province, have been used extensively in folk medicine for many years and provide additional income to local people, who collect and sell the plants (Karik, 2015). However, many factors, such as irregular construction, intense grazing, and unconscious harvests in Mugla province-where many plant species are distributed naturally-can cause reduced populations of these species and jeopardize their continuity. The degradation or disintegration of these natural populations may lead to differentiation in the genetic structure of populations due to gene flow and genetic drift between species (Hatmaker et al., 2018). To prevent a possible genetic erosion, a gene database should be determined using molecular methods for economically valuable, endemic, and endangered species; furthermore, gene banks should be set up, and genetic resources of these species should be protected (Altindal, 2019).

Production of superior genotypes that will provide economic benefits by determining and manipulating genetic and chemical diversity can be beneficial for economic development. Salvia fruticosa Mill. is a species of high medicinal and economic value, so it is important to investigate its utilizability and sustainability in future studies. Characterization of the diversity of essential oils of Salvia fruticosa Mill. and the comparison of molecular characterization can contribute to the opportunity to grow homogeneous plant material with desired commercial characteristics such as stable essential oil profile. This study will provide insight into the future studies to obtain superior genotypes and to benefit from them in commercial breeding studies. In future studies on Salvia fruticosa Mill. it is recommended to investigate genetic differences and identify agriculturally important genes using different molecular markers (ISSR, SSR etc.) together with chemical and morphological characteristic analyzes.

\section{The limitations of the study are as follows:}

1. Soil analysis of the locations where Salvia fruticosa Mill. populations were collected was not performed. Therefore, other than genetic diversity, the cause of the wide variation in the population and between populations may be related to many ecological factors, including soil structure, temperature, precipitation, sunshine duration and intensity, altitude, drought, and salinity.

2. The study was conducted at the end of the flowering period of Salvia fruticosa Mill., and in each population, the plant material collection hours were different. In previous 
studies, the highest essential oil rates of Salvia fruticosa Mill. was reported in May-June, before flowering or at the beginning of flowering, and at noon when the active components reached their peaks. In addition, various factors affect the yield and quality of the essential oil of the plants, including the age of the plant; climatic, seasonal, and geographical conditions; harvest time of the plant; drying methods; part of the plant; and distillation technique (Altindal, 2019).

Acknowledgments. This article was developed from a doctoral thesis titled 'Determination of Morphological, Chemical and Molecular Characterization of Salvia fruticosa Mill. Populations Distributed in Mugla Province Naturally'. The project was supported by Mugla Sitki Kocman University Scientific Research Projects Unit, project number 17/213. It was also presented as an oral paper at the 2nd International Congress on Agriculture, Environment and Health at Adnan Menderes University and 1st International Symposium on Biodiversity Research at Canakkale Onsekiz Mart University.

\section{REFERENCES}

[1] Aljanabi, S. M., Forget, L., Dookun, A. (1999): An improved and rapid protocol for the isolation of polysaccharide-and polyphenol-free sugarcane DNA. - Plant Molecular Biology Reporter 17(3): 281-282.

[2] Altindal, D. (2019): Determination of genetic diversity of natural sage populations in Mugla region of Turkey. - International Journal of Environmental Science and Technology 16(9): 5219-5226.

[3] Arikat, N. A., Jawad, F. M., Karam, N. S., Shibli, R. A. (2004): Micropropagation and accumulation of essential oils in wild sage (Salvia fruticosa Mill.). - Scientia Horticulturae 100(1-4): 193-202.

[4] Bacu, A., Konkjika, E., Mullaj, A. (2005): Molecular characterization of Salvia officinalis and Salvia triloba grown in Albania. - Albanian Journal of Natural and Technical Sciences (1), X (17): 65-71.

[5] Bayram, E. (2001): A study on selecting suitable types of the Anatolia sage (Salvia fruticosa Mill.) in the flora of western Anatolia. - Turkish Journal of Agriculture and Forestry 25(6): 351-357. (in Turkish).

[6] Chrysargyris, A., Laoutari, S., Litskas, V. D., Stavrinides, M. C., Tzortzakis, N. (2016): Effects of water stress on lavender and sage biomass production, essential oil composition and biocidal properties against Tetranychus urticae (Koch). - Scientia horticulturae 213: 96-103.

[7] Elmas, S. (2019a): Determination of morphological, chemical and molecular characterization of Salvia fruticosa Mill. populations distributed in Mugla province naturally. - Mugla Sitki Kocman University, Institute of Science Department of Biology, PhD Thesis, Mugla, Turkey. (in Turkish).

[8] Elmas, S., Arabac1, O., Zeybek, A. (2019b): Determination of some agricultural characteristics and essential oil amounts of Salvia fruticosa Mill. populations in Mugla province. - Mediterranean Agricultural Sciences 32(2): 243-249. (in Turkish).

[9] Guner, A., Ozhatay, N., Ekim, T., Baser, K. H. C. (2001): Flora of Turkey and the east Aegean Islands. - Edinburgh University Press, Edinburgh.

[10] Hatmaker, E. A., Staton, M. E., Dattilo, A. J., Hadziabdic, D., Rinehart, T. A., Schilling, E. E., Trigiano, R. N., Wadl, P. A. (2018): Population structure and genetic diversity within the endangered species Pityopsis ruthii (Asteraceae). - Frontiers in Plant Science 9: 943.

[11] Javan, Z. S., Rahmani, F., Heidari, R. (2012): Assessment of genetic variation of genus' Salvia' by RAPD and ISSR markers. - Australian Journal of Crop Science 6(6): 1068. 


$$
-1421-
$$

[12] Karik, U. (2015): Some Morpholocigal, Yield and Quality Characteristics of Anatolian Sage (Salvia fruticosa Mill.) Populations in Aegean and West Mediterranean Region. Journal of Tekirdag Agricultural Faculty 12(2): 32. (in Turkish).

[13] Karousou, R., Kokkini, S. (1997): Distribution and clinal variation of Salvia fruticosa Mill. (Labiatae) on the island of Crete (Greece). - Willdenowia 27(1-2): 113-120.

[14] Mossi, A. J., Cansian, R. L., Paroul, N., Toniazzo, G., Oliveira, J. V., Pierozan, M. K., Pauletti, G., Rota, L., Santos, A. C. A., Serafini, L. A. (2011): Morphological characterisation and agronomical parameters of different species of Salvia sp.(Lamiaceae). - Brazilian Journal of Biology 71(1): 121-129.

[15] Nei, M. (1978): Estimation of average heterozygosity and genetic distance from a small number of individuals. - Genetics 89(3): 583-590.

[16] Peakall, R., Smouse, P. E. (2012): GenAlEx 6.5: Genetic analysis in Excel. Population genetic software for teaching and research-an update. - Bioinformatics 28(19): 2537-2539.

[17] Skoula, M., El Hilali, I., Makris, A. M. (1999): Evaluation of the genetic diversity of Salvia fruticosa Mill. clones using RAPD markers and comparison with the essential oil profiles. - Biochemical Systematics and Ecology 27(6): 559-568.

[18] TUIK. (2019): Foreign Trade Statistics. - Available at: https://biruni.tuik.gov.tr/disticaretapp/disticaret.zul?param1=25\&param2=0\&sitcrev=0\&i sicrev $=0 \&$ sayac $=5802$, (Accessed December 03.2019).

[19] Uysal, F. (2015): Determining superior genotypes by selective breeding of Anatolian sage (Salvia fruticosa Mill.) populations in the flora of Antalya. - Akdeniz University Institute of Science Department of Field Crops, PhD Thesis, Antalya, Turkey. (in Turkish).

[20] Wang, M., Li, J., Zhang, L., Yang, R. W., Ding, C. B., Zhou, Y. H., Yin, Z. Q. (2011): Genetic diversity among Salvia miltiorrhiza Bunge and related species using morphological traits and RAPD markers. - Journal of Medicinal Plants Research 5(13): 2687-2694.

[21] Wichtl, M. (1971): Die fharmakognostisch-Chemische Analyse. - Gehaltsbestimmung von Drogen (und Zubereitungen) mit atherischem 1: 263-281. (in German). 